УДК 614.777:(477.53):351.777.6:549.755-034

(C) 2012

Коваль В. В., директор,

Наталочка В. О., завідувач лабораторії екологічної безпеки земель та якості продукції,

Ткаченко С. К., завідувач лабораторії експериментальних досліджень, проектно-технологічної документації та інформаційного забезпечення, Міненко О. В., завідувач лабораторї̈ агрохімічної паспортизації земель, моніторингу та охорони родючості трунтів

Полтавський обласний державний проектно-технологічний центр охорони родючості грунтів і якості продукції

\title{
ДИНАМІКА ЗАБРУДНЕННЯ ВОД СІЛЬСЬКОГОСПОДАРСЬКОГО ПРИЗНАЧЕННЯ СОЛЯМИ ВАЖКИХ МЕТАЛІВ В УМОВАХ ПОЛТАВЩИНИ
}

\section{Рецензент - доктор сільськогосподарських наук, професор П. В. Писаренко}

\begin{abstract}
Лабораторними дослідженнями, проведеними
Полтавським обласним державним проектнотехнологічним иентром охорони родючості грунтів і якості продукиії на протязі 2002-2008 років, встановлено, щзо води Полтавської області не забруднені солями важких металів. Дані умови дозволяють нашому регіону розвивати агроекологічну сферу й у майбутньому стати лідером у виробництві високоякісних продуктів харчування, особлив, екологічно чистої продукції. Однак необхідною передумовою даного прочесу є наявність об 'єктивної інформації щуодо агроекологічного стану трунтових та водних ресурсів $і$ застосовуваних способів землекористування в умовах екологічного стану, щзо склався й залишається відносно стабільним. За результатами досліджень останніх років, екологічна ситуація на Полтавщині залишається однією з найкращих в Украӥні.
\end{abstract}

Ключові слова: ГДК (гранично допустима концентрація), стічні води, важкі метали, кадмій, свинець, ртуть, мідь, циинк.

Постановка проблеми. Вода - це найтаємничіша речовина, про яку відомо нашим науковцям. Вона має пам'ять, у неї є безліч унікальних властивостей, які роблять можливим життя на планеті Земля. Одна $з$ таких властивостей полягає в тому, що вода - найбільш універсальний розчинник. Саме тому ідеально чистої води, або хоча б придатної для пиття, на нашій планеті не так уже й багато, про що говорять не тільки лікарі, які першими забили на сполох, спостерігаючи за зростаючою кількістю людей, які страждають від хвороб нирок, печінки та інших органів, але навіть політики! А футурологи прогнозують у майбутньому війни за запаси питної води.

Безперервний ріст кількості міст, промислових підприємств і створення великих тваринницьких комплексів супроводжується збільшенням обсягу побутових, промислових і сільськогоспо- дарських стічних вод, стік яких призводить до значного забруднення довкілля. Речовини, що містяться в стічних водах, потрапляючи у водойми, істотно змінюють хімічний склад природних вод, погіршують якість.

Високо мінералізовані води, що містять токсичні речовини й патогенну міклофлору, потрапляють на зрошувальні поля. Тут забруднювачі поглинаються грунтом і рослинами, мігрують у підгрунтові води, частково повертаються у водойми 3 поверхневим стоком.

Найнебезпечнішими для грунтового покриву $\epsilon$ стічні води хімічної промисловості, що містять цинк, свинець, ртутні сполуки, хром, фтор, метанол, меланін.

Щоб запобігти забрудненню вод солями важких металів і звести до мінімуму надходження їх у стічні води, для вжиття відповідних природоохоронних заходів Полтавський обласний державний проектно-технологічний центр охорони родючості грунтів і якості продукції проводить постійний моніторинг та оцінку якісного стану водних джерел, згідно з нормативним документом [5].

Аналіз основних досліджень і публікацій, у яких започатковано розв'язання проблеми. У даний час у грунтах, донних відкладеннях, поверхневих, підземних водах і інших об'єктах навколишнього середовища України зосереджена значна кількість антропогенних забруднювачів. У процесі сільськогосподарського виробництва до грунту внесені складові ртуті, миш'яку, брому й т. д. Спостерігається поступова міграція антропогенних забруднювачів у поверхневі й підземні води, продукти харчування, організм людини.

У складі промислових викидів нараховують близько 10-20 хімічних елементів. Однак у найбільших кількостях трапляються і завдають най- 
більшої шкоди 4-6 елементів. На металургійних заводах утворюються характерні зони забруднення свинцем, цинком, кадмієм, ртуттю, міддю; біля свинцево-плавильних підприємств крім свинцю та цинку головними забруднювачами $є$ кадмій, мідь, ртуть, арсен, селен. Високий вміст міді та нікелю фіксується навколо комбінатів кольорової металургії, забруднення хромом характерно для довкілля цементних заводів і нафтопереробних підприємств [7].

Кадмій має надзвичайно високу токсичність, кумулятивні властивості. Він знижує здатність організму людини протистояти хворобам, має мутагенні й канцерогенні властивості, впливає на спадкоємність, а також руйнує еритроцити крові, сприяє захворюванню нирок і сім'яних залоз, викликає гастрит і анемію [3]. Для людини допустима доза становить 70 мкг для дорослих і повністю виключає його наявність у питній воді та їжі для дітей.

Основним джерелом кадмію $є$ промислові викиди, значним носієм його є осади стічних вод. Із 100 т осаду в грунт вноситься 4-5 мг кадмію [4].

Істотним джерелом свинцю $є$ осади комунальних і промислових стічних вод. При внесенні у грунт до 100 т/га стічних вод вміст свинцю в орному шарі підвищується на 4,5 мг/кг грунту [2]. Після перемішування 3 грунтом відходів, що містять свинець, він у значній мірі переходить у малорухомі сполуки; при цьому близько 20-30 \% його залишається в рухомому стані й засвоюється рослинами.

Ртуть і їі сполуки надзвичайно токсичні для людини - вони акумулюються в нирках, печінці, головному мозку. Основний орган-мішень для неорганічної ртуті - нирки. Метилртуть вражає головним чином центральну нервову систему. Летальна доза ртуті при споживанні 3 питною водою складає 75-300 мг/добу. Симптоми ртутної інтоксикації - атаксія, пригнічення периферійного сприйняття і рефлексу кінцівок.

Мідь є одним із незамінних елементів для організму людини. В деяких випадках дефіцит міді за симптомами подібний до хронічної інтоксикації нею. Споживання міді 3 їжею зазвичай складає 2-3 мг/добу, що підтримує необхідну рівновагу. Мідь малотоксична для людини, не має кумулятивних властивостей. Звичайно, швидкість поглинання, утримання і виведення міді не призводять до підвищеного їі вмісту в організмі. Однак при хворобах, що викликають порушення цього механізму, тривала абсорбція міді може викликати цироз печінки. $€$ відомості про вплив міді на метаболізм штучно вигодуваних новонароджених. Зафіксовані гострі отруєння людей за вживання з питною водою міді при дозі 0,14 мг/кг і вище. Канцерогенні й мутагенні властивості міді не встановлені.

За даними «Агроекологічного атласу Полтавщини» [1], в 2007 році була здійснена комплексна оцінка стану вод на основних водних об'єктах області та їх приток: Кременчуцькому та Дніпродзержинському водосховищах, річок Ворскла, Псел, Хорол, Сула, Удай, Коломак, Кобелячок, Сухий Кобелячок, Ташань, Говтва, Орчик, Тагамлик, Солониця, Оржиця, Артополот, Сухий Омельник, Татарка, Крива Руда та інших. Дослідження якісного стану вод даних об'єктів проводилися за вмістом хлоридів, сульфатів, азоту аміаку, нітритів, нафтопродуктів. Відносно проведеної оцінки й визначеного індексу забруднення вод (IЗВ) здійснено ранжування водних об'єктів за сімома можливими класами якості вод (I-VII - від дуже чистих до надзвичайно брудних). За якістю вод водні об'єкти області переважно відносяться до III класу (помірно забруднені): річки Дніпро (Кременчуцьке водосховище), Хорол, Ворскла, Коломак, Псел. До II класу (чистих) відносяться річки Сула, Оржиця, Удай.

Незадовільним $є$ стан малих річок області.

За результатами досліджень більшість із них віднесено до III класу вод (помірно забруднених): р. Сухий Омельник, Ташань, Кобелячка, Оріль, Гнила Оржиця, Сулиця, Солониця. Найбільш забрудненими малими річками (VI клас вкрай забруднені води) є: р. Суха Лохвиця, Орчик, Тагамлик, Багачка.

Найгірший якісний стан вод спостерігається у Дніпродзержинському водосховищі, який коливається від III (помірно забруднені) до VII класу вод (надзвичайно брудні), що характерно для вод у районі м. Комсомольська.

Найбільш чистими річками в області є: р. Артополот, Крива Руда, Татарка, Удай Кобелячок, Сухий Кагамлик і з основних річок - лише р. Сула.

За даними ВООЗ, надходження на стаціонарне лікування кожного четвертого хворого обумовлено забрудненням води водопроводів. З'явилися особливі захворювання, пов'язані із забрудненням води хімічними елементами: «міномата» - при вживанні води забрудненої сполуками ртуті, молібденова подагра - у випадку хронічного отруєння молібденом. Доведено, що чинниками, які сприяють розвитку ендемічного зобу, є високий вміст у воді гумінових кислот, зміна концентрації міді, цинку, ртуті, кобальту, молібдену, кальцію. 
СІЛЬСЬКЕ ГОСПОДАРСТВО. РОСЛИННИЦТВО

\section{1. Забруднення важкими металами стічних вод та інших вододжерел}

\begin{tabular}{|c|c|c|c|c|c|}
\hline \multirow{2}{*}{ Хімічні елементи } & \multirow{2}{*}{$\begin{array}{c}\text { Проаналізо- } \\
\text { вано проб }\end{array}$} & \multirow{2}{*}{$\begin{array}{c}\text { Забруднених } \\
\text { вище ГДК }\end{array}$} & \multicolumn{3}{|c|}{ Вміст хімічних елементів, мг/л } \\
\hline & & & мінімальний & середній & максимальний \\
\hline \multicolumn{6}{|c|}{2002 рік } \\
\hline Цинк & 60 & - & 0,005 & 0,04 & 0,15 \\
\hline Мідь & 60 & - & 0,003 & 0,05 & 0,11 \\
\hline Кадмій & 60 & 6 & 0,003 & 0,008 & 0,018 \\
\hline Свинець & 60 & - & 0,01 & 0,02 & 0,05 \\
\hline Ртуть & 60 & - & 0,0005 & 0,001 & 0,0025 \\
\hline \multicolumn{6}{|c|}{2003 рік } \\
\hline Цинк & 63 & - & 0,01 & 0,04 & 0,14 \\
\hline Мідь & 63 & - & 0,01 & 0,04 & 0,09 \\
\hline Кадмій & 63 & - & 0,001 & 0,004 & 0,009 \\
\hline Свинець & 63 & - & 0,01 & 0,02 & 0,05 \\
\hline Ртуть & 63 & - & 0,0005 & 0,0009 & 0,0025 \\
\hline \multicolumn{6}{|c|}{2004 рік } \\
\hline Цинк & 61 & - & 0,001 & 0,04 & 0,154 \\
\hline Мідь & 61 & - & 0,006 & 0,038 & 0,088 \\
\hline Кадмій & 61 & - & 0,002 & 0,004 & 0,009 \\
\hline Свинець & 61 & - & 0,004 & 0,026 & 0,0096 \\
\hline Ртуть & 61 & - & 0,0005 & 0,0012 & 0,004 \\
\hline \multicolumn{6}{|c|}{2005 рік } \\
\hline Цинк & 61 & - & 0,008 & 0,041 & 0,125 \\
\hline Мідь & 61 & - & 0,005 & 0,035 & 0,080 \\
\hline Кадмій & 61 & - & 0,0015 & 0,0039 & 0,009 \\
\hline Свинець & 61 & - & 0,004 & 0,030 & 0,09 \\
\hline Ртуть & 61 & - & 0,0005 & 0,0019 & 0,0042 \\
\hline \multicolumn{6}{|c|}{2006 рік } \\
\hline Цинк & 60 & - & 0,010 & 0,042 & 0,15 \\
\hline Мідь & 60 & - & 0,006 & 0,038 & 0,1 \\
\hline Кадмій & 60 & - & 0,0015 & 0,0036 & 0,009 \\
\hline Свинець & 60 & - & 0,004 & 0,029 & 0,061 \\
\hline Ртуть & 60 & - & 0,0005 & 0,001 & 0,0042 \\
\hline \multicolumn{6}{|c|}{2007 рік } \\
\hline Цинк & 60 & - & 0,005 & 0,029 & 0,0825 \\
\hline Мідь & 60 & - & 0,0075 & 0,037 & 0,105 \\
\hline Кадмій & 60 & - & 0,00125 & 0,005 & 0,008 \\
\hline Свинець & 60 & - & 0,0025 & 0,03 & 0,095 \\
\hline Ртуть & 60 & - & 0,0005 & 0,001 & 0,0042 \\
\hline \multicolumn{6}{|c|}{2008 рік } \\
\hline Цинк & 61 & - & 0,01 & 0,034 & 0,085 \\
\hline Мідь & 61 & - & 0,015 & 0,05 & 0,49 \\
\hline Кадмій & 61 & - & 0,00075 & 0,005 & 0,0097 \\
\hline Свинець & 61 & - & 0,005 & 0,03 & 0,097 \\
\hline Ртуть & 61 & - & 0,0005 & 0,001 & 0,0042 \\
\hline
\end{tabular}

Мета досліджень та методика їх проведення. Мета досліджень - постійний моніторинг та оцінка якісного стану водних джерел Полтавсь- кої області за період із 2002 по 2008 рік.

Дослідження виконувались у відповідності до існуючих нормативних актів та методичних вка- 
зівок. Визначення у вододжерелах вмісту свинцю, кадмію, цинку, міді і ртуті проводилося згідно 3 «Методическими рекомендациями по спектрофотометрическому определению тяжелых металлов в объектах окружающей среды, полимерах и биологических материалах» [5].

Результати досліджень. Для проведення хіміко-аналітичних досліджень у Полтавському обласному державному проектно-технологічному центрі охорони родючості грунтів і якості продукції є атестована випробувальна лабораторія, яка має спеціалізовану аналітичну лабораторію, оснащену сучасними засобами вимірювальної техніки, випробувальним обладнанням, а також висококваліфікованими фахівцями, які атестовані з правом пробопідготовки та виконання вимірювань. Хіміко-аналітичні дослідження виконуються згідно з офіційно затвердженими методиками.

Матеріалом для проведення досліджень були зразки води, які з 2002 року по 2008 рік відбиралися спеціалістами Полтавського обласного державного проектно-технологічного центру охорони родючості грунтів і якості продукції із стоків сільськогосподарських угідь, із криниць, водогонів, водосховищ і водоканалів. У тім числі: 4 зразки води відбиралося з Дніпродзержинського, Кременчуцького, Бабичівського і водосховища с. Пулинці Лубенського району, одна 3 водоканалу Дніпро-Донбас, 17 проб із річок Дніпро, Сула, Псел, Ворскла, Оріль, Удай, Оржиця, Мерла і Середня Говтва, 17 зразків - iз закритих водогонів, 16 зразків із криниць та 6 зразків - у ставках.

Відбір проб води проводився в п'яти контрольних точках Великобагачанського та Глобинського районів, по 2 контрольні точки в Диканському, Машівському, Пирятинському, Семенівському, Чорнухинському районах, по 3 контрольні точки в Кобеляцькому, Кременчуцькому, Лохвицькому, Миргородському, Новосанжарському, Оржицькому та Хорольському районах, по 4 контрольні точки в Котелевському та Лубенському, в одній - Решетилівського, та в 11 контрольних точках Полтавського району. Кожного року, в середньому, відбиралася 61 проба води.

Відібрані зразки води було проаналізовано на вміст свинцю, кадмію, цинку, міді й ртуті. Результати лабораторних досліджень по забрудненню вод, що стікають із сільськогосподарських угідь та інших вододжерел солями важких металів, подано в таблиці 1. Перевищення ГДК (гранично допустима концентрація по вмісту ртуті становить 0,005 мг/л, кадмію - 0,01 мг/л, свинцю - 0,1 мг/л, цинку і міді - 1,0 мг/л) по вмісту ртуті, цинку, свинцю і міді не виявлено, а вміст кадмію вище ГДК виявлено в 2002 році у шести зразках води.

Зокрема перевищення ГДК за вмістом кадмію виявлено в р. Говтві Решетилівського району $(0,015$ мг/л), у водогоні м. Глобино $(0,015$ мг/л), в криниці по вулиці Ударна, 4 м. Глобино (0,018 мг/л), у криниці по вулиці Миргородська, 32 в с. Великі Сорочинці Миргородського району $(0,015$ мг/л), в криниці с. Нехвороща Новосанжарського району, вулиця Леніна, 32 $(0,018$ мг/л) і водогоні смт. Оржиця $(0,018$ мг/л).

Кадмій має токсичні й кумулятивні властивості. При надходженні в організм він накопичується в печінці, нирках і селезінці, а також викликає анемію, знижує вміст кисню в крові. Нирки $є$ основною мішенню токсичної дії кадмію. Метал викликає хворобу «ітай-ітай», що проявляється в розм'якшенні кісток, кальцифікації й пієлонефриті нирок. Оскільки кадмій накопичується в органах і має тривалий період напіввиведення (10-30 років), вживання заражених продуктів протягом тривалого часу може призвести до тих чи інших форм кадмієвої інтоксикації. Тому виявленню його в воді в наступні роки надавалася перевага, але фоновий рівень його після 2002 року (за нашими дослідженнями) не перевищував гранично допустимих концентрацій.

Висновки. Нашими дослідженнями встановлено, що води сільськогосподарського призначення Полтавської області не забруднені солями важких металів. Дані умови дозволяють нашому регіону розвивати агроекологічну сферу й у майбутньому стати лідером у виробництві високоякісних продуктів харчування, i особливо, екологічно чистої продукції. Однак необхідною передумовою даного процесу $€$ наявність об'єктивної інформації щодо агроекологічного стану грунтових та водних ресурсів і застосовуваних способів землекористування в умовах екологічного стану, що склався й залишається відносно стабільним у період 2002-2008 років. За результатами досліджень останніх років екологічна ситуація на Полтавщині залишається однією з найкращих в Україні.

Важкі метали широко застосовуються в різноманітних промислових виробництвах, тому, незважаючи на очисні заходи, вміст сполук важких металів у промислових стічних водах досить високий. Значна кількість цих сполук надходить у воду й через атмосферу. Екологічна небезпека важких металів полягає в тому, що вони активно поглинаються фітопланктоном, а після цього 
передаються по харчовому ланцюгу до людини. Тому при організації системи екологічного моніторингу й оцінці шкідливого впливу на організм

\section{БІБЛІОГРАФІЯ}

1. Голік Ю. С., Ілляш О. Е., Шуліка А. О. [та ін.] Агроекологічний атлас Полтавщини. Полтава: Оріяна. - 2009. - 68 с.

2. Гармаш Г. А., Гармаш Н. Ю. Влияние тяжелых металлов, внесенных в почву с осадками сточных вод, на урожайность пшеницы и качество продукции // Агрохимия. - 1989. № 7. С. 69-75.

3. Минеев В. Г, Макаров А. И., Тришина Т. А. Тяжелые металлы и окружающая среда в условиях современной интенсивной химизации. Кадмий // Агрохимия. - 1981 - № 5-6. - С. 146155.

4. Минеев В. Г., Алексеев А. А., Манзерова Е. М. Поступление тяжелых металлов в почвы при людини особлива увага повинна приділятися вмісту важких металів у водах сільськогосподарського призначення та їх токсичній дії.

внесении высоких доз минеральных удобрений // Докл. ВАСХНИЛ. - 1981 - № 7. - С. 8-9.

5. Методические рекомендации по спектрохимическому определению тяжелых металлов в объектах окружающей среды, полимерах и биологическом материале. - Одесса, Одесский филиал НИИ гигиены водного транспорта. $-1986 .-28$ с. 6. Рахов Г. М., Петров Р. В., Цапко В. В. Влияние применения ядохимикатов и удобрений в водоохранной зоне с источниками пополнения запасов подземных вод // Гигиена и санитария. 1976 - № 3. - С. 101-102.

7. Охорона грунтів: навч. посіб. (М. К. Шикула, О.Ф. Ігнатенко, Л. Р. Петренко [та ін.]) - К.: Знання, КОО. - 2004. - 398 с. 